\title{
SDS POLYACRYLAMIDE GEL ELECTROPHORESIS OF CHROMATIN PROTEINS FROM YEAST DURING VEGETATIVE GROWTH AND SPORULATION
}

\author{
by
}

\author{
JENS G. LITSKE PETERSEN
}

Department of Physiology, Carlsberg Laboratory

Gamle Carlsberg Vej 10, DK-2500 Copenhagen Valby

Keywords: Saccharomyces cerevisiae, meiosis, nuclei, chromosomes

\begin{abstract}
Chromatin was isolated from yeast during vegetative growth and sporulation by differential centrifugation after breaking the cells with glass beads. The preparations were analysed by SDS polyacrylamide gel electrophoresis. Three prominent stained polypeptide bands, molecular weights $51,000,49,000$ and 48,000 were observed in chromatin from a sporulating culture with the majority of cells in meiotic prophase. The bands were absent or very faint in chromatin from cells growing exponentially in glucose medium and from stationary cells. The 51,000 molecular weight band was also found in chromatin from cells growing exponentially in acetate growth medium. The 49,000 and 48,000 polypeptides can be extracted from chromatin with $0.25 \mathrm{M}$ hydrochloric acid and with $0.6 \mathrm{M}$-sodium chloride. They seem to increase in concentration between 0 and 6 hours in sporulation medium, and were found with similar intensities in chromatin from sporulating and nonsporulating diploids in sporulation medium. No other polypeptide differences in chromatin between sporulating and non-sporulating cells were observed.
\end{abstract}

\section{INTRODUCTION}

Diploid strains of Saccharomyces cerevisiae, heterozygous for mating-type (MATa/MATa), can be induced to undergo synchronous meiosis and sporulation when vegetative cells in an oxidative state are transferred to a potassium acetate medium $(3,17)$.
In most sporulation procedures, the majority of cells undergo meiotic DNA replication between 3 and 8 hours $(5,6,12,16)$. This process is followed by pairing of homologous chromosomes at pachytene $(2,25)$, whereafter the nucleus goes through meiosis giving rise to four haploid spores in an ascus. Soon after the cells

Abbreviations: PSP2 = acetate vegetative medium; SDS = sodium dodecyl sulfate; SPM $=$ sporulation medium; SPO = sporulation medium containing low amounts of glucose and yeast extract. 
enter meiotic DNA replication they become committed to genetic recombination between homologous chromosomes $(4,19)$.

It may be expected that the nuclear events during the early stages of sporulation are accompanied by the synthesis of new chromosomal proteins necessary for replication, pairing and recombination. In several studies meiosis specific proteins have been searched for by comparison of protein patterns in one- and twodimensional gels from whole yeast cell lysates (6, $7,8,11,22,24)$. In a recent study of the folded chromosomes of yeast evidence for a few meiosis specific polypeptides was obtained (13). The yield of proteins associated with the folded chromosomes was low, so that they could only be detected by the use of in vivo labelling with ${ }^{35} \mathrm{~S}$ methionine and autoradiography. In order to investigate whether meiosis specific proteins associated with chromatin exist in yeast a rapid method for extraction of crude chromatin was developed. In this paper I present one-dimensional gel patterns of polypeptides in chromatin preparations from various stages of yeast growth and sporulation.

\section{MATERIALS AND METHODS}

\subsection{Strains}

Two diploid, sporulating yeast strains of Saccharomyces cerevisiae were used, strain 11D (12) and strain 131 (20). Both strains are $M A T \mathrm{a} / M A T \alpha$. As non-sporulating, diploid strains were used C77-11NS2 (MATa/MATa)

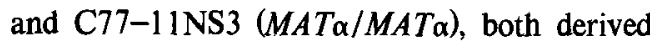
from $11 \mathrm{D}(\mathrm{II})$.

\subsection{Presporulation and sporulation conditions}

Sporulation of strain 11D was achieved by using the high cell density sporulation procedure described earlier (12). In this system strain 11D is grown to stationary phase in glucose presporulation medium $(0.8 \%$ Bacto yeast extract, $0.3 \%$ Bacto peptone, $10 \%$ glucose, $\mathrm{pH}$ 6.5), and induced to undergo synchronous meiosis and sporulation by the transfer to SPO sporulation medium ( $1 \%$ potassium acetate, $0.1 \%$ Bacto yeast extract, $0.05 \%$ glucose, $\mathrm{pH} 6.5$ ) at a cell density of approx. $2.5 \cdot 10^{8} \mathrm{cells} \cdot \mathrm{ml}^{-1}\left(25^{\circ} \mathrm{C}\right)$. This procedure was also used to study non- sporulating strains under sporulation conditions.

The sporulation procedure for strain 131 was that described by SiMCHEN et al. (20) employing PSP2 acetate presporulation medium and SPM sporulation medium.

\subsection{Isolation of chromatin}

The following method was used to isolate chromatin from yeast. The procedure is a modification of that described by BHARGAVA and Halvorson (1) and SAJDEl-SulKowsKa et al. (18) for isolating nuclei.

A vegetative or a sporulating culture of $1-2$. $10^{11}$ cells was cooled on ice and harvested by centrifugation at $6,000 \mathrm{rpm}$ for $5 \mathrm{~min}$ in the Sorvall GSA rotor at $0^{\circ} \mathrm{C}$. All subsequent steps were performed at $0-4{ }^{\circ} \mathrm{C}$. The cell pellet was washed twice with deionized water by resuspension and centrifugation, and weighed. Then the cells, usually 20-35 grams, were resuspended in $3 / 4$ volumes of homogenization buffer $(20 \%$ (w/v) glycerol, $1.0 \mathrm{M}$-sorbitol, 7\% (w/v) $\mathrm{Fi}$ coll-400 (Pharmacia), $3 \mathrm{~mm}-\mathrm{CaCl}_{2}, 10 \mathrm{~mm}$ $\mathrm{NaCl}, 1 \mathrm{~mm}$-phenylmethylsulfonyl fluoride, 10 mM-Tris- $\mathrm{HCl}, \mathrm{pH} 8$ ). The cell suspension was divided in $10 \mathrm{ml}$ aliquots which were homogenized with 3-4 volumes of $0.45 \mathrm{~mm}$ glass beads in a Braun Melsungen MSK homogenizer for $60-90$ seconds at $2,000 \mathrm{rpm}$. The cell lysate was removed from the glass beads using $20-30 \mathrm{ml}$ of homogenization buffer per $10 \mathrm{ml}$ lysate to rinse the beads. The homogenates were pooled and centrifuged in $30-40 \mathrm{ml}$ portions in the Sorvall SS-34 rotor at $7,000 \mathrm{rpm}$ for $10 \mathrm{~min}$ followed by $10,000 \mathrm{rpm}$ for $10 \mathrm{~min}$, discarding the pellets. Chromatin was spun down from the supernatant at $15,000 \mathrm{rpm}$ for $20 \mathrm{~min}$, washed in a total volume of $20 \mathrm{ml}$ homogenization buffer and centrifuged at $15,000 \mathrm{rpm}$ for 20 min. The chromatin (containing some intact nuclei) was resuspended in $2 \mathrm{ml}$ homogenization buffer and stored frozen at $-70{ }^{\circ} \mathrm{C}$ in $0.5 \mathrm{ml}$ aliquots.

For analysis by electrophoresis an $0.5 \mathrm{ml}$ chromatin sample was thawed on ice, $5 \mathrm{ml}$ homogenization buffer was added and the suspension centrifuged in the SS-34 rotor at $15,000 \mathrm{rpm}$ for $20 \mathrm{~min}$. The pellet was washed twice in $3 \mathrm{ml}$ of $0.14 \mathrm{M}-\mathrm{NaCl}, 5 \mathrm{~mm}-\mathrm{Tris}-\mathrm{HCl}$, $\mathrm{pH} 7.8$, by resuspensions and centrifugations at 
$8,000 \mathrm{rpm}$ for $10 \mathrm{~min}$ in the SS-34 rotor. The resulting pellet of saline washed chromatin was then resuspended in $0.25 \mathrm{ml}$ SDS sample buffer (9), boiled for $5 \mathrm{~min}$ and analysed by SDS polyacrylamide gel electrophoresis.

\subsection{Isolation of yeast nuclei}

Nuclei were prepared from strain 11D grown exponentially in 4 litres of YPD ( $1 \%$ Bacto yeast extract, $2 \%$ Bacto peptone, $2 \%$ glucose) at 30 ${ }^{\circ} \mathrm{C}$ by the protoplast-Ficoll method as described earlier (14). Approximately 0.03 grams of nuclei (the pellet resulting from sedimentation through $30 \%$ Ficoll at $\left.100,000 \times \mathrm{g}_{\max }\right)$ was washed twice with cold $0.14 \mathrm{M}-\mathrm{NaCl}, 5 \mathrm{~mm}-\mathrm{Tris}-\mathrm{HCl}$, $\mathrm{pH} 7.8$, as described above. The washed nuclei were dissolved in $0.25 \mathrm{mi}$ SDS sample buffer.

\section{5. ${ }^{35} \mathrm{~S}$-labelled proteins in chromatin and folded chromosomes}

Strain 11D was grown to stationary phase in $10 \mathrm{ml}$ of glucose presporulation medium with 5 ${ }_{\mu \mathrm{Ci}} \cdot \mathrm{ml}^{-1}$ of $\left[{ }^{35} \mathrm{~S}\right]$ methionine (New England Nuclear), $30^{\circ} \mathrm{C}$. The cells were then transferred to SPO medium with $10 \mu \mathrm{Ci} \cdot \mathrm{ml}^{-1}$ $\left.{ }^{35} \mathrm{~S}\right]$ methionine at a cell concentration of 2.4 . $10^{8}$ cells $\cdot \mathrm{ml}^{-1}$. After 6 hours in sporulation medium chromatin was prepared as described above except that smaller volumes of homogenization buffer were used. The final, saline washed chromatin pellet was divided into two parts. One part was solubilized in $0.4 \mathrm{ml}$ SDS sample buffer. The other was extracted once with 0.25 $\mathrm{M}-\mathrm{HCl}$ and centrifuged and the proteins in the extract were precipitated with acetone. The washed and dried proteins were solubilized in $0.2 \mathrm{ml}$ SDS sample buffer.

The $g_{1}$ and $g_{2}$ forms of the folded genome of strain 131 were isolated from an exponential culture in PSP2 acetate medium supplemented with $40 \mu \mathrm{g} \cdot \mathrm{ml}^{-1}$ adenine and containing $20 \mu \mathrm{Ci}$ - $\mathrm{ml}^{-1}\left[{ }^{35} \mathrm{~S}\right.$ ] methionine as described by PETERSEN and PIÑON (13). The isolation of the meiotic replicating form, $r$, and the $g_{o}$ form was done by growing strain 131 in $10 \mathrm{ml} \mathrm{PSP2}$ acetate growth medium to $0.7 \cdot 10^{7}$ cells $\cdot \mathrm{ml}^{-1}$ followed by 7 hours in $10 \mathrm{ml}$ SPM sporulation medium with $20 \mu \mathrm{Ci} \cdot \mathrm{ml}^{-1}$ [35S]methionine, and preparing folded chromosomes. The analysed $r$ and $g_{o}$ forms were collected from the same sucrose gradient.

\subsection{Acid soluble proteins}

Chromatin proteins were separated in acid soluble and acid insoluble components with hydrochloric acid in the following manner. One frozen aliquot was washed with saline as described above, resuspended in $1 \mathrm{ml} 0.25 \mathrm{M}$ $\mathrm{HCl}$ and left on ice for $30 \mathrm{~min}$ with occasional mixing. The suspension was centrifuged in the SS-34 rotor for $20 \mathrm{~min}$ at $20,000 \mathrm{rpm}, 2^{\circ} \mathrm{C}$, and the pellet was reextracted with the acid. The supernatants were combined, and the acid extracted proteins were precipitated overnight at $-20^{\circ} \mathrm{C}$ with 8 volumes of acetone. Precipitated protein was pelleted by centrifugation at 13,000 $\mathrm{rpm}$ for $10 \mathrm{~min}, 2^{\circ} \mathrm{C}$, washed once with cold acetone, air dried and stored at $-20^{\circ} \mathrm{C}$. For analysis the proteins were solubilized in $0.10 \mathrm{ml}$ SDS sample buffer. The pellet from the acid extractions (acid insoluble material) was washed in $5 \mathrm{ml}$ of cold acetone $-0.1 \mathrm{M}-\mathrm{HCl}(6: 1 \mathrm{v} / \mathrm{v})$ by resuspension and centrifugation at $13,000 \mathrm{rpm}$ for $10 \mathrm{~min}$, washed once in acetone, air dried and stored at $-20^{\circ} \mathrm{C}$. The pellet was solubilized in $0.15 \mathrm{ml}$ SDS sample buffer for analysis.

\subsection{Fractionation with salt}

A sample of saline washed chromatin was extracted three times with $2 \mathrm{ml} 0.6 \mathrm{M}-\mathrm{NaCl}, 1$ mM-phenylmethylsulfonyl fluoride by resuspensions and centrifugations at $20,000 \mathrm{rpm}$ in the SS-34 rotor for $20 \mathrm{~min}, 2{ }^{\circ} \mathrm{C}$. The three supernatants were pooled $(0.6 \mathrm{M}$ extract $)$. The pellet was extracted three times in the same way with $2.0 \mathrm{M}-\mathrm{NaCl}, 1 \mathrm{~mm}$-phenylmethylsulfonyl fluoride. The two extracts were cleared by centrifugation at $33,000 \mathrm{rpm}$ for 1 hour in the Beckman 50Ti rotor, $2{ }^{\circ} \mathrm{C}$, and the proteins precipitated by adding $80 \%(\mathrm{w} / \mathrm{v})$ trichloroacetic acid to a final concentration of $15 \%$, leaving the suspensions on ice for 1 hour. The precipitated proteins were collected by centrifugation in the SS-34 rotor at $13,000 \mathrm{rpm}$ for $10 \mathrm{~min}, 2^{\circ} \mathrm{C}$. The two protein precipitates as well as the pellet from the $2 \mathrm{M}-\mathrm{NaCl}$ extraction (salt insoluble material) were washed, first in acetone $-0.1 \mathrm{~N}$ $\mathrm{HCl}(6: 1 \mathrm{vol} / \mathrm{vol})$, then in acetone, air dried and 
stored at $-20{ }^{\circ} \mathrm{C}$. For analysis, the precipitates were taken up into SDS sample buffer, the $0.6 \mathrm{M}$ extract in $1 \mathrm{ml}$, the $2 \mathrm{M}$ extract in $0.5 \mathrm{ml}$ and the salt insoluble material in $2.5 \mathrm{ml}$.

\subsection{Yeast ribosomes}

Ribosomes were prepared from a 2 liter YPD culture of strain $11 \mathrm{D}$ according to the method of WARNER (23).

\subsection{SDS polyacrylamide gel electrophoresis}

Sodium dodecyl sulfate polyacrylamide gel electrophoresis was performed according to Laemmli (9) as modified by THOMAs and KorNBERG (21). The following concentrations of acrylamide to $\mathbf{N}, N^{\prime}$-bis-methylene acrylamide in the separating gel were used: $18-0.09$ and 18$0.12 \%(\mathrm{w} / \mathrm{v})$. The proteins were stained with Coomassie Brilliant Blue R-250 (Sigma). Molecular weight estimates of polypeptides were done in a 10-0.27 gel by comparison to the mobilities of rabbit immunoglobulin $\mathrm{G} 150,000$, bovine serum albumin 69,000 , catalase 62,500 , ribulose diphosphate carboxylase, large subunit 55,000 , rabbit immunoglobulin $\mathrm{G}$ heavy chain 52,000 , chymotrypsinogen 24,700 , rabbit immunoglobulin $\mathrm{G}$ light chain 22,500 , myoglobin 17,000 , calf histone $\mathrm{H} 3 \quad 15,300$, lysozyme 14,400 , calf histone $\mathrm{H} 2 \mathrm{~B} 14,000$, bovine ribonuclease A 13,700, calf histone H2A 13,700, cytochrome $\mathrm{C} 12,400$, calf histone $\mathrm{H} 411,300$. Gel electrophoresis and autoradiography of $\left.{ }^{35} S\right]$ methionine labelled proteins were carried out as described by Petersen and Piñon (13).

\section{RESULTS}

\subsection{Isolation of chromatin, nuclei and folded chromosomes}

In initial stages of the present study various methods to prepare chromosomal proteins from yeast were compared. The method for isolation of chromatin described in section 2.3. was chosen as being easy, rapid and applicable to exponential, stationary as well as sporulating yeast. The yield of DNA in a chromatin pellet isolated from a sporulating culture of strain 11D was measured to be $10 \%$ of the total cell content of labelled DNA (12) and 6\% of the DNA was

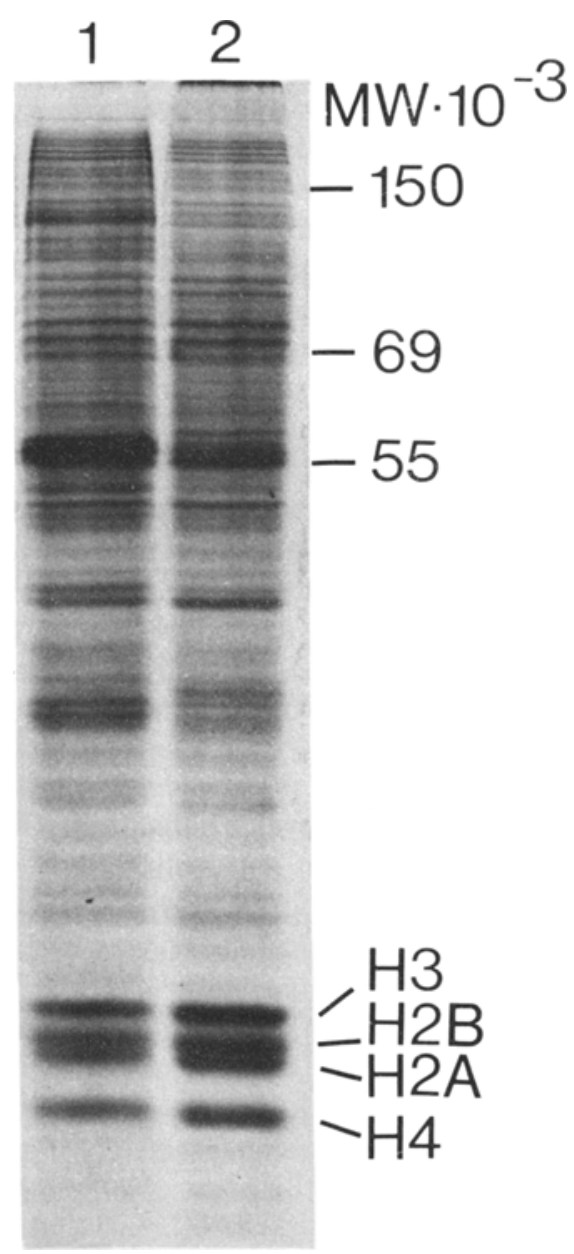

Figure 1. SDS polyacrylamide gel electrophoresis patterns of polypeptides in isolated chromatin and nuclei from yeast.

Lane 1: Chromatin was isolated from a 2 litre YPD culture $\left(30^{\circ} \mathrm{C}\right)$ of strain IID during exponential growth $\left(3 \cdot 10^{7}\right.$ cells $\left.\cdot \mathrm{ml}^{-1}\right)$ as described in section 2.3. Lane 2: Nuclei were isolated from strain 11D during exponential growth as described in section 2.4. Gel 18-0.09\%.

recovered in the saline washed chromatin. The purity of the saline washed chromatin was estimated by electron microscopy as follows. Strain 11D was harvested during exponential growth as well as during sporulation, chromatin was prepared, fixed, stained with uranyl acetatelead citrate, embedded and sectioned. It showed 
mainly two components: Darkly stained material, interpreted to be chromatin, and membranes.

Figure 1 shows a comparison of the SDS polyacrylamide gel patterns of chromatin (lane 1) and nuclei isolated by the protoplast-Ficoll method (lane 2) from strain 11D during exponential growth in glucose presporulation medium. Rather similar patterns were obtained. The nuclei seemed to contain a somewhat higher concentration of the four core histones. The isolation procedure for nuclei was unsuccessful with sporulating yeast.

In Figure 2 is shown an autoradiogram of ${ }^{35} \mathrm{~S}$ labelled polypeptides from chromatin and folded chromosomes. Strain 11D was grown to stationary phase in glucose presporulation medium with $\left.{ }^{35} S\right]$ methionine and the cells transferred to SPO medium which also contained [ ${ }^{35}$ S]methionine. After 6 hours chromatin was prepared (lane 1). An aliquot was extracted with hydrochloric acid. The acid extractable polypeptides are shown in lane 2. Lanes 3,4 and 5 contain three different forms of folded genomes from strain 131 , namely $g_{l}$, meiotic $r$ and $g_{0}$. Strain 131 was used rather than $11 \mathrm{D}$, since labelling and growth conditions for the preparation of folded genomes were worked out for strain 131 $(13,15,20)$. Similarities as well as differences are observed between the chromatin preparation (lane 1) and the folded genome preparations. The most noticeable difference is that the yeast histones (acid extractable polypeptides) are much more efficiently labelled in the chromatin preparation. The four polypeptides of the meiotic $r$ form that were noted in a previous study (13) as polypeptides possibly specific for meiosis are marked with arrows in lane 4. Only the low molecular weight band seems to correspond to a polypeptide in the chromatin from sporulating cells in lane 1.

\subsection{Chromatin from vegetative and sporulating yeast}

Chromatin was isolated from strain 11D during exponential growth in glucose presporulation medium, from a stationary culture in glucose presporulation medium (these cells readily initiate meiosis and sporulation when transferred to SPO medium) and from a sporulating culture at 7 hours in SPO medium (at this stage the majority of cells were in meiotic prophase (12)). Stained electropherograms of the three samples are shown in Figure 3, lanes 1, 2 and 3, respectively. The corresponding hydrochloric acid extracts are shown in lanes 4,5 and 6. Lane 7 shows a sample of calf thymus histones. Five major polypeptide bands are common to the three acid extracts, namely the four yeast histones $\mathrm{H} 3, \mathrm{H} 2 \mathrm{~A}, \mathrm{H} 2 \mathrm{~B}$ and $\mathrm{H} 4$, and a 55,000 molecular weight band. In addition two bands with apparent molecular weights 49,000 and 48,000 are observed with much greater intensity in the acid extract from the sporulating culture. These two bands are also seen in the unextracted chromatin sample (lane 3) with greatly increased intensities as compared to the two other chromatin samples. In addition the 7 hour chromatin sample in lane 3 seems to contain an additional (or strongly increased ) 51,000 band, and perhaps an extra 46,000 band (marked with arrows).

In a further attempt to find out to which extent the gel pattern of chromatin from sporulating cells was related to meiosis and sporulation, chromatin was isolated from strain $11 \mathrm{D}$ growing exponentially in acetate growth medium (1\% Bacto yeast extract, 2\% Bacto peptone, $2 \%$ potassium acetate). The gel pattern is shown in Figure 4, lane 1. A sample of chromatin from glucose grown cells (YPD, but $5 \%$ glucose) is shown in lane 2 , and chromatin from cells at 7 hours in sporulation medium is shown in lane 3. An intense 48,500 polypeptide band, a 51,000 band and a minor 46,000 band are observed in chromatin from sporulating cells. These bands are absent, or present in only low concentrations, in chromatin from glucose grown cells. On comparison with the chromatin sample from acetate grown cells (lane 1) it is noted that this sample contains a strong 51,000 polypeptide. Several other differences are observed between chromatin from acetate grown cells and the other two chromatin preparations, but only the 48,500 band, and perhaps the 46,000 band, are found exclusively in chromatin from sporulating cells. When the chromatin from sporulating cells is run in gels with less crosslinker (18-0.09) the 48,500 band is resolved into a 49,000 and a 48,000 band, as examplified in Figure 3. 
J. G. L. Petersen: Yeast chromosomal proteins

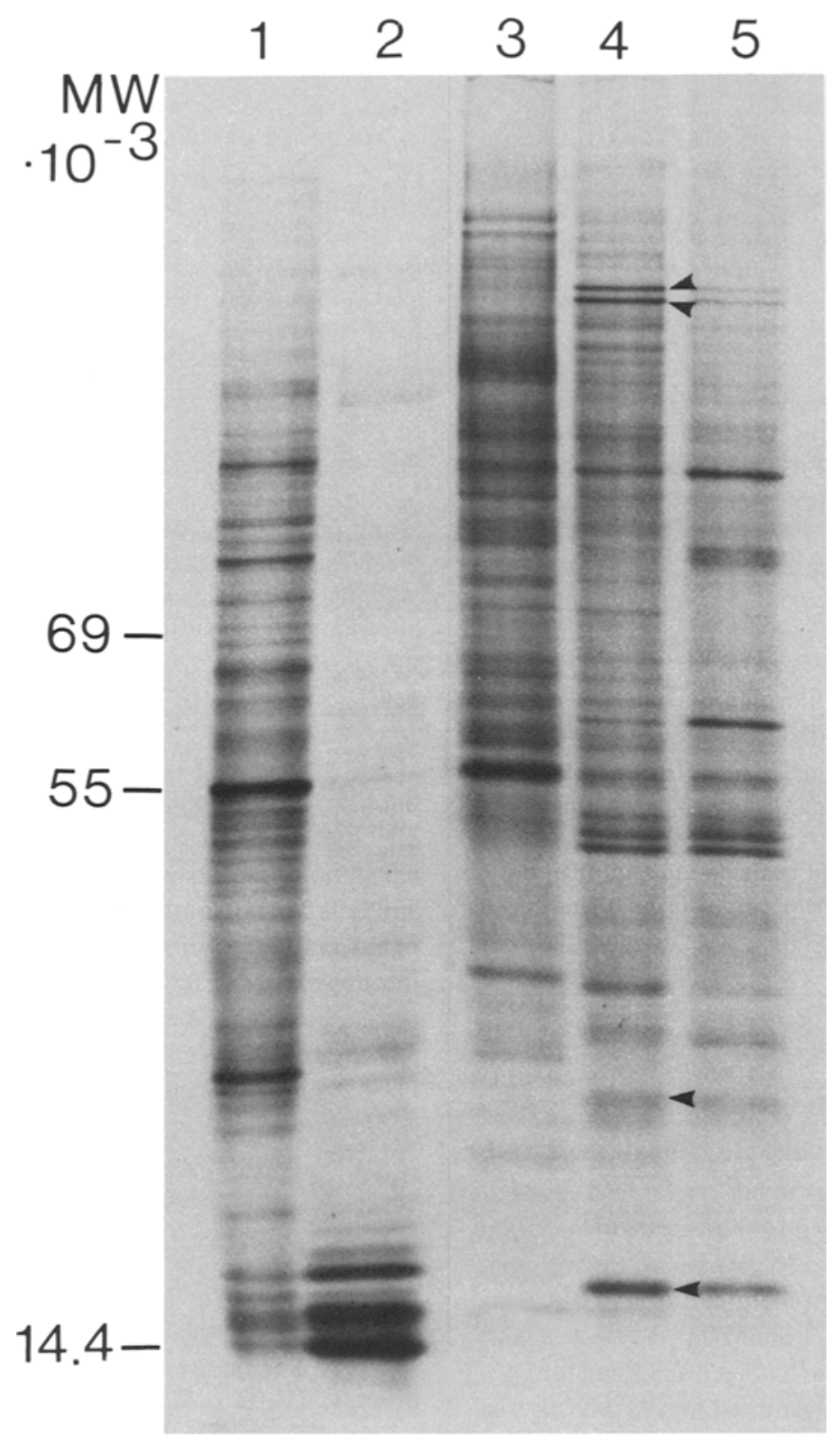

Figure 2. Autoradiogram of $35 \mathrm{~S}$-labelled polypeptides associated with isolated chromatin and folded chromosomes.

Lane 1: Chromatin was isolated from strain 11D at 6 hours in sporulation medium containing [35S]methionine as described in section 2.5. The sample on the gel contained 36,000 cpm. Lane 2: Hydrochloric acid extractable proteins from the chromatin in lane $1(33,000 \mathrm{cpm})$. Lane 3 : The $g_{1}$ form of folded chromosomes from strain $131,33,000 \mathrm{cpm}$. Lane 4: The meiotic replicating form, $r$, of strain 131, isolated at 7 hours in SPM medium, $32,000 \mathrm{cpm}$. Four polypeptides previously shown to be possible meiosis specific polypeptides (13) are marked. Lane 5: The go of strain 131, isolated at 7 hours in SPM, 32,500 cpm. The polypeptides were separated in a 8-18\% gradient gel (13). The exposure time was 25 days. 


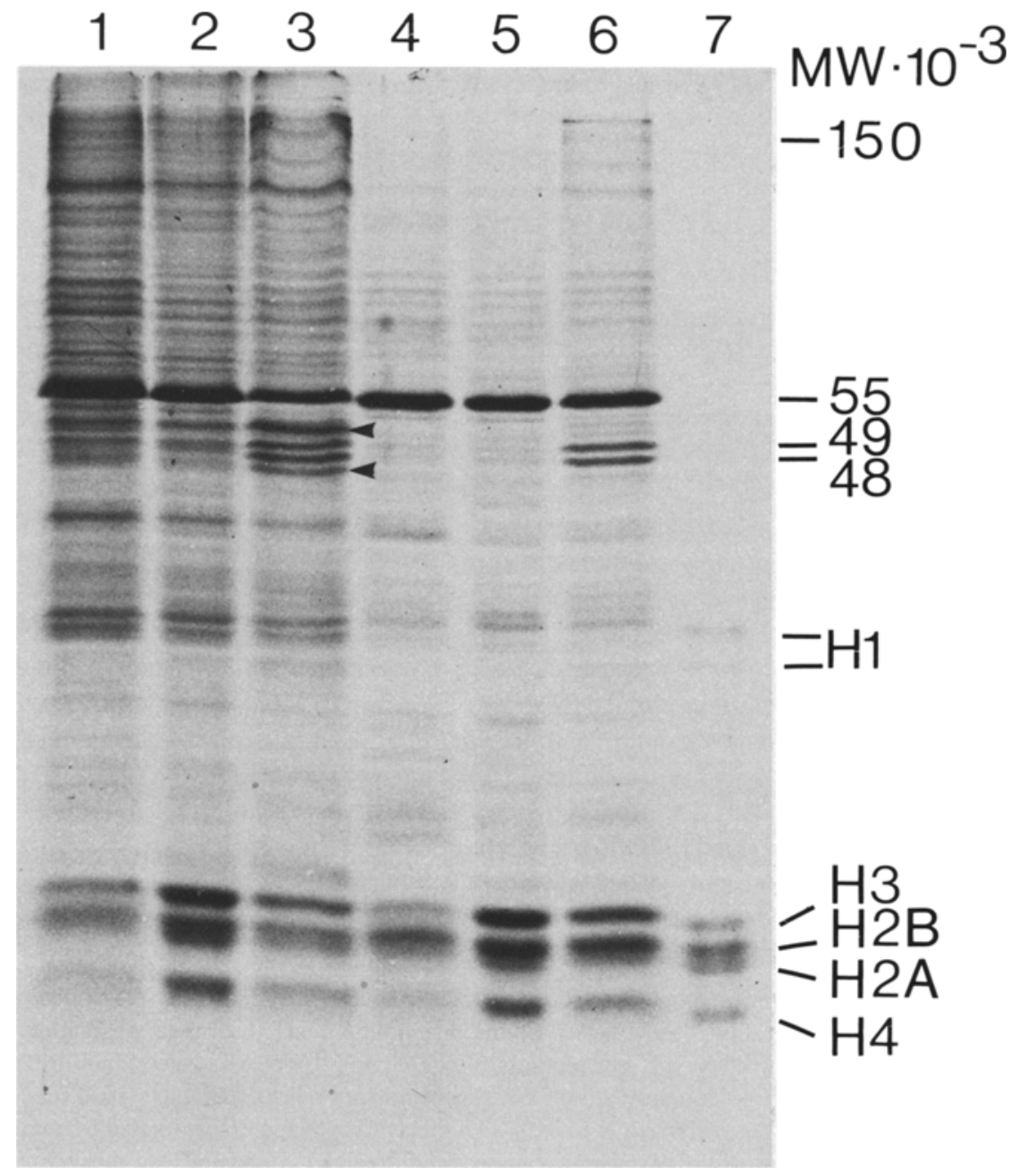

Figure 3. Chromatin proteins of strain 11D in presporulation medium and during sporulation.

Lane 1: Chromatin from cells growing exponentially in glucose presporulation medium $\left(3\right.$ litres, $25^{\circ} \mathrm{C}, 5$. $10^{7}$ cells $\left.\cdot \mathrm{ml}^{-1}\right)$. Lane 2: Chromatin from stationary cells in glucose presporulation medium $\left(0.75\right.$ litres, $25^{\circ} \mathrm{C}$, 3.5 $\cdot 10^{8}$ cells $\cdot \mathrm{ml}^{-1}$ ). Lane 3: Chromatin from cells after 7 hours in sporulation medium ( 1 litre, $25^{\circ} \mathrm{C}, 2.3$. $10^{8}$ cells $\cdot \mathrm{ml}^{-1}$ ). Two polypeptides, molecular weights 51,000 and 46,000 are marked with arrows. Lane 4: Hydrochloric acid extractable proteins of the chromatin in lane 1. Lane 5: Acid extract of the chromatin in lane 2. Lane 6: Acid ectract of the chromatin in lane 3. Lane 7: Calf thymus histones (Sigma), $4 \mu \mathrm{gg}$. Gel 18-0.09\%.

\subsection{Gel patterns of ribosomal proteins}

Ribosomal proteins are a serious contaminant in some methods for preparing chromatin (10). The possibility for this being the case in the present method was judged by comparisons between the gel patterns of isolated chromatin and the patterns of isolated yeast ribosomes. This is shown in Figure 5. Lane 3 contains ribosomal proteins. Lane 1 shows chromatin from strain $11 \mathrm{D}$ at 7 hours in sporulation medium, and lane 2 contains the corresponding hydrochloric extract. The ribosomal contamination is negligible. 


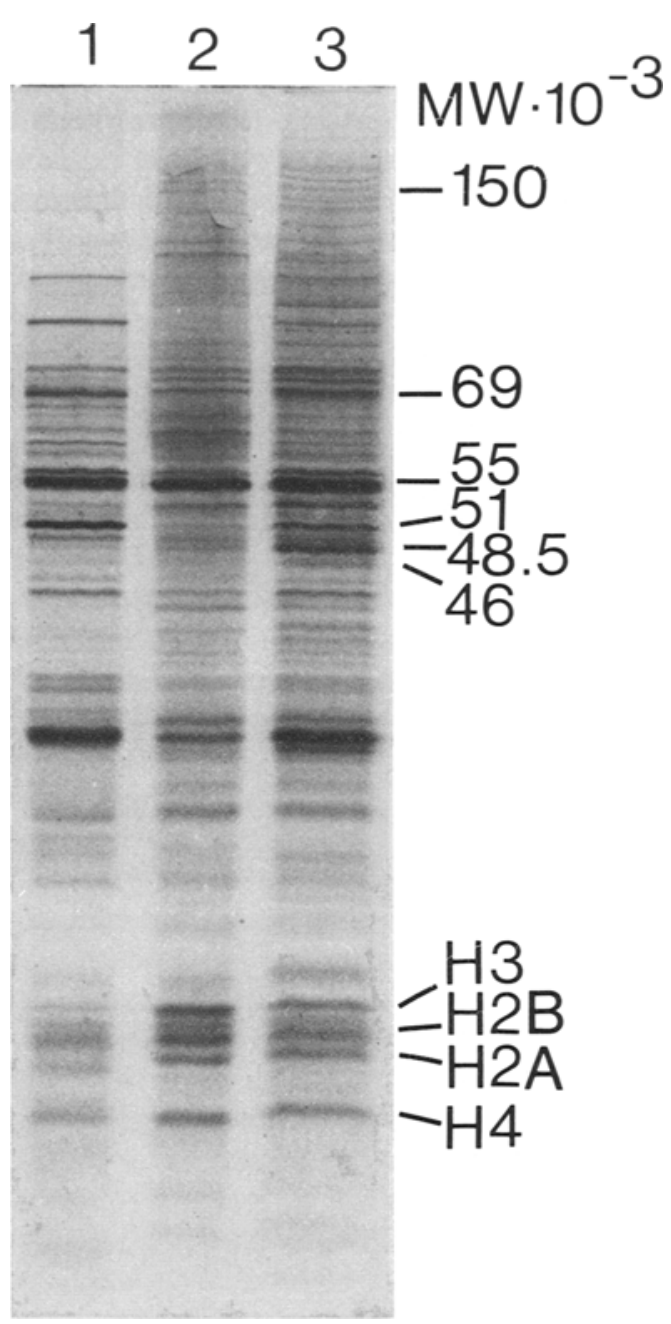

Figure 4. Chromatin proteins of strain 11D during oxidative growth.

Lane 1: Chromatin from strain 11D in acetate growth medium ( $1 \%$ yeast extract, $2 \%$ peptone, $2 \%$ potassium acetate, a 3 litre culture at $30^{\circ} \mathrm{C}, 1.0 \cdot 10^{7}$ cells $\cdot \mathrm{ml}^{-1}$ ). Lane 2: Chromatin from an exponential culture of strain 11D in a glucose growth medium ( $1 \%$ yeast extract, $2 \%$ peptone, $5 \%$ glucose, a 4 litre culture at $30{ }^{\circ} \mathrm{C}, 8 \cdot 10^{7}$ cells $\cdot \mathrm{ml}^{-1}$ ). Lane 3: Chromatin from strain IID at 7 hours in sporulation medium. Gel 18-0.12\%.

\subsection{Chromatin at various times of sporulation}

Chromatin was isolated from strain 11D at 0 , 3, 6 and 9 hours in SPO medium, and the acid extracts were compared by electrophoresis (Fig- ure 6, lanes 2, 3, 4 and 5, respectively). The two polypeptide bands with molecular weights of 48,000 and 49,000 seem to increase in concentration from 0 to 6 hours. Other differences were not observed.

\subsection{Non-sporulating strains in sporulation medium}

In order to further study the meiosis specificity of the gel pattern obtained from strain IID

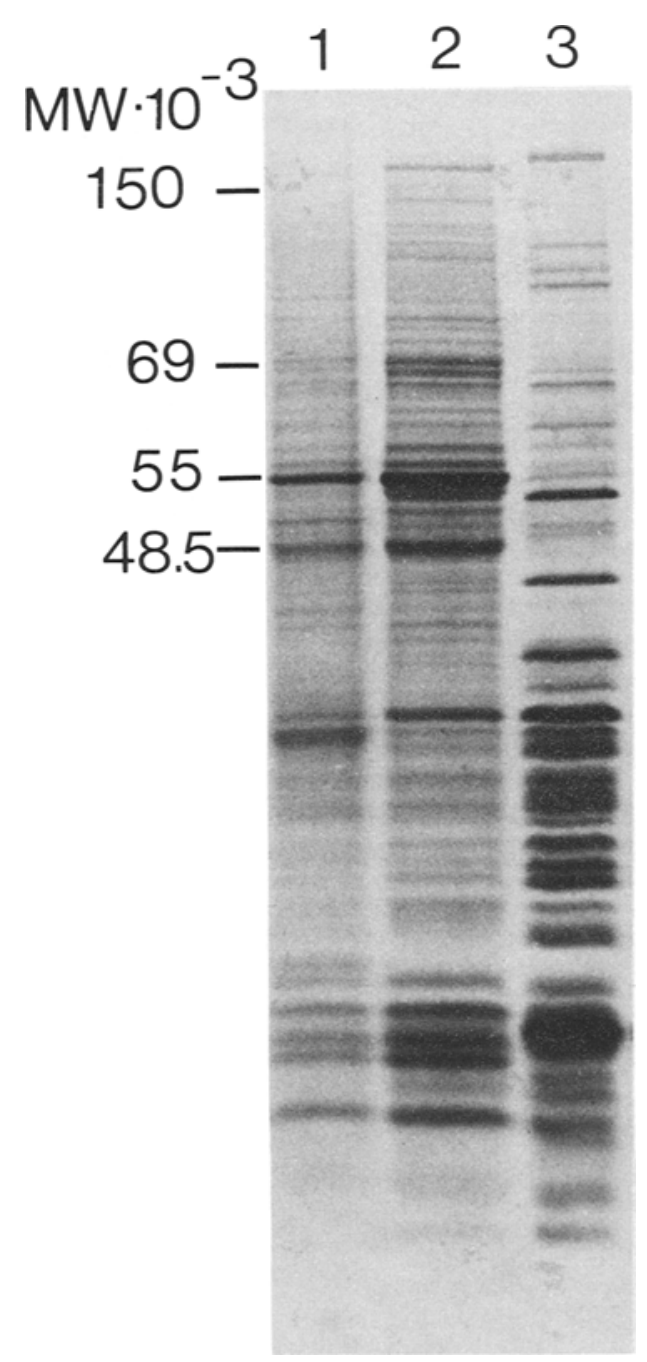

Figure 5. Chromatin and ribosomal proteins.

Lane 1: Chromatin from strain 11D after 7.5 hours in sporulation medium. Lane 2: Acid extractable proteins from chromatin isolated at 7.5 hours in sporulation medium. Lane 3: Yeast ribosomal proteins. 


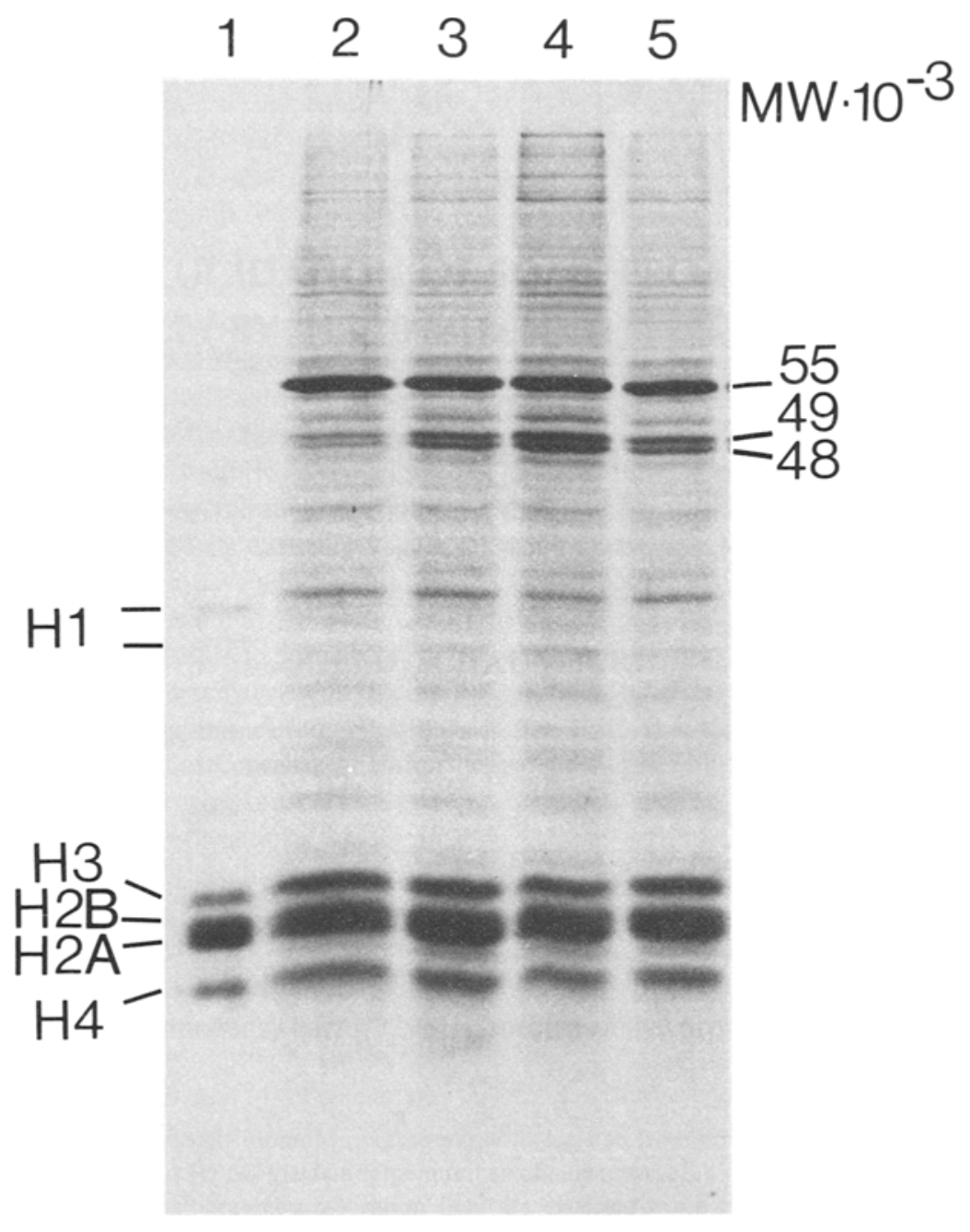

Figure 6. Acid extractable proteins of chromatin at various times during sporulation.

Strain 1 ID was grown to stationary phase in glucose presporulation medium and transferred to SPO medium (cultures of 0.75 litres, $25^{\circ} \mathrm{C}, 2.5 \cdot 10^{8}$ cells $\cdot \mathrm{ml}-1$ ). Immediately after the transfer (time 0 hours) and at 3,6 and 9 hours chromatin was isolated and subjected to extraction with hydrochloric acid. Lane 1: Calf thymus histones, $4 \mu \mathrm{g}$. Lanes 2-5: Acid extracts at 0, 3, 6 and 9 hours, respectively. Gel 18-0.09\%.

in sporulation medium, chromatin was isolated from strain $11 \mathrm{D}$ and the two non-sporulating, diploid strains C77-11NS2 (MATa/MATa) and C77-1 INS3 (MAT $\alpha / M A T \alpha)$ at time 7.5 hours in SPO medium. These two strains have been derived from strain $11 \mathrm{D}$ by UV-irradiation, screening for non-sporulators, and were found to be diploid maters. They are therefore essentially isogenic with 11D. Figure 7 shows the patterns of chromatin from the three strains (lanes 1, 2 and 3), the corresponding acid extractable proteins are shown in lanes 4,5 and 6 , and acid insoluble proteins are run in lanes 7,8 and 9. No consistent differences were observed between the three strains; a few polypeptide differences noticeable between the acid soluble proteins of $11 \mathrm{D}$ (lane 4) and the non-sporulating diploids (lanes 5 and 6) were not reproducible. 


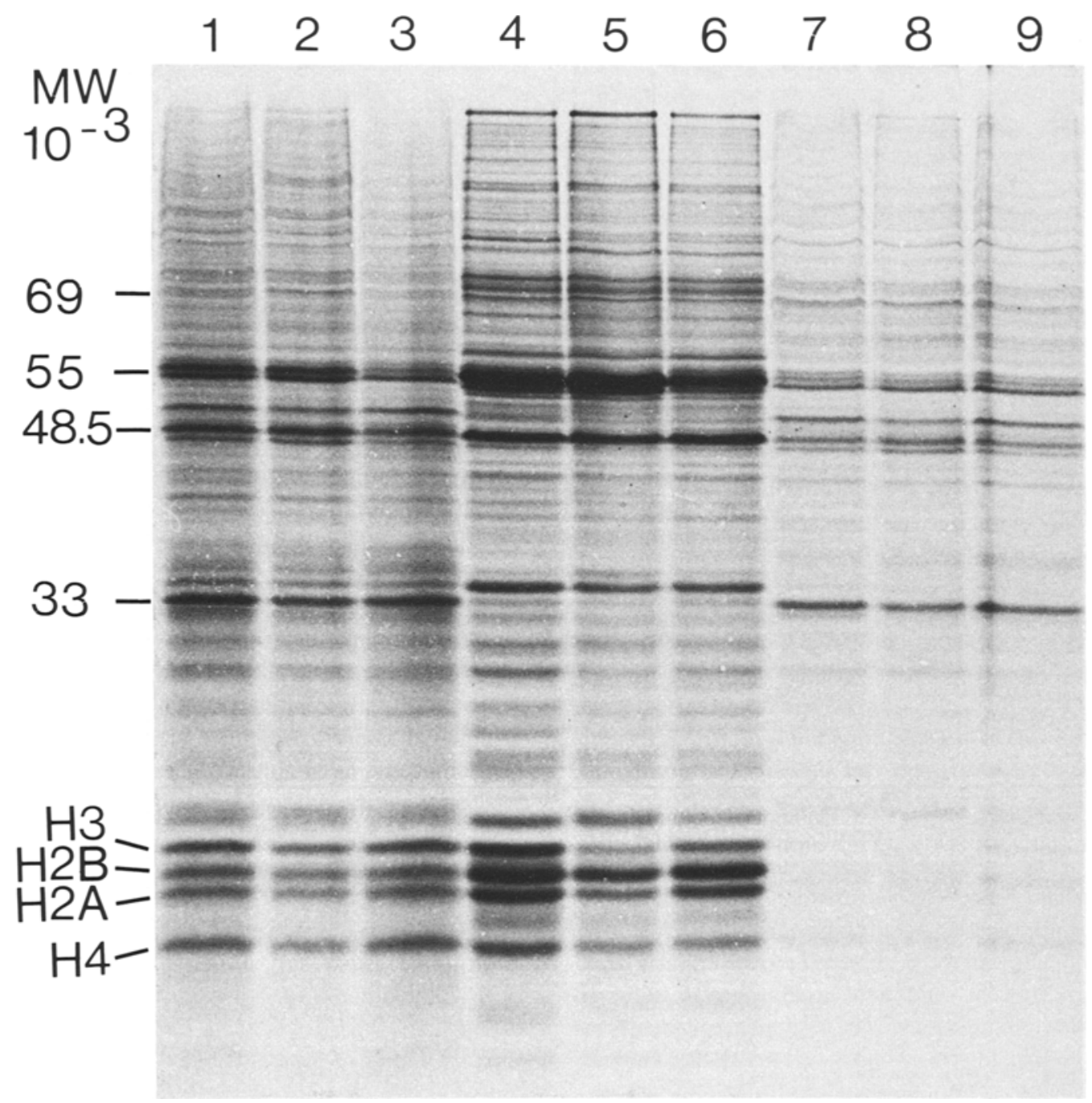

Figure 7. Chromatin from sporulating and non-sporulating diploids in sporulation medium.

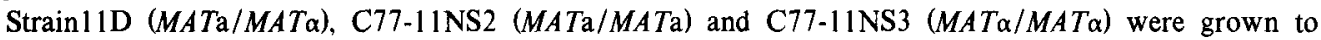
stationary phase in glucose presporulation medium and transferred to 0.75 litre SPO medium at a cell density of $2.5 \cdot 10^{8}$ cells $\cdot \mathrm{ml}^{-1}, 25^{\circ} \mathrm{C}$. After 7.5 hours chromatin was prepared. Lanes 1-3: chromatin of 11D, C77-11 NS2 and C77-11NS3, respectively. Lanes 4-6: Acid extractable proteins, corresponding to lanes 1-3. Lanes 7-9: Acid insoluble proteins, corresponding to lanes 1-3. Gel 18-0.12\%.

\subsection{Fractionation of chromatin with salt}

A sample of chromatin from strain 11D harvested at 7 hours in sporulation medium was fractionated with increasing concentrations of sodium chloride as described in section 2.7. The result is shown in Figure 8. Unfractionated chromatin is shown in lane 4 . Lane 1 contains the polypeptides extracted with $0.6 \mathrm{M}-\mathrm{NaCl}$. A number of bands are observed, including the major 55,000 molecular weight band. The subsequent extraction with $2 \mathrm{~m}-\mathrm{NaCl}$ releases another series of polypeptides (lane 2). One of the major bands is the 48,500 band characteristic of cells in sporulation medium. The histones are 


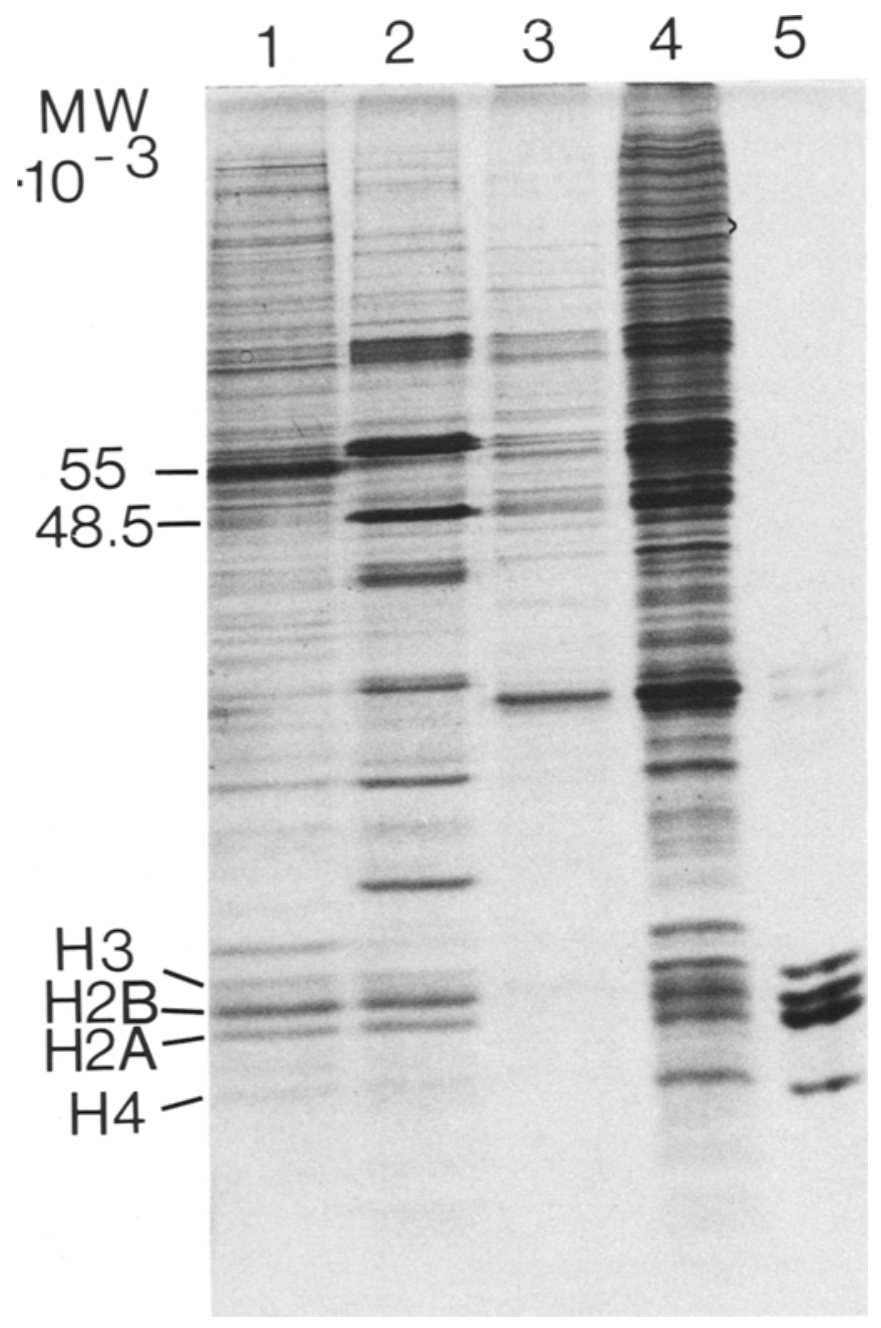

Figure 8. Salt extraction of proteins from isolated chromatin.

Chromatin from strain $1 \mathrm{DD}$ harvested at 7 hours in SPO medium was subjected to extraction with increasing concentrations of sodium chloride as described in section 2.7. Lane 1: Proteins extracted with $0.6 \mathrm{M}-\mathrm{NaCl}$. Lane 2: Proteins extracted with $2.0 \mathrm{M}-\mathrm{NaCl}$. Lane 3: Proteins in the $2 \mathrm{M}-\mathrm{NaCl}$ insoluble fraction. Lane 4: Unfractionated chromatin. Lane 5: Calf thymus histones, $10 \mu \mathrm{g}$. Gel $18-0.12 \%$.

also extracted predominantly in this fraction. In the pellet remaining after extraction with $2 \mathrm{M}$ $\mathrm{NaCl}$, lane 3, the 51,000 and 46,000 bands are prominently represented.

\section{DISCUSSION}

The experiments presented above were performed in an attempt to identify possible meiosis specific proteins in yeast. Rather than studying whole yeast cell lysates, which so far have given only limited evidence for the existence of such proteins $(6,7,8,11,22,24)$, a restricted class of proteins were analyzed by electrophoresis. The chromatin isolation method has the advantage of being fast, and all steps are carried out at low temperatures, restricting proteolysis. It cannot be excluded that the preparations are contaminated with other yeast cell components of a particulate nature. In fact, electron microscopy showed the 
presence of membraneous material, but the chromatin is free of ribosomal proteins (Figure $5)$, which is a contaminant in yeast chromatin prepared by other procedures (10).

In order to evaluate the differences in gel patterns of chromosomal proteins obtainable with various preparations, chromatin was compared to yeast nuclei (Figure 1) and to folded chromosomes (Figure 2). Quite similar stained patterns were obtained for chromatin and nuclei, while the autoradiograms of labelled polypeptides in chromatin and folded genomes showed several differences. Some of these may be due to the different growth and labelling conditions employed and to strain specificities.

Three, possibly four, polypeptide bands were characteristic for chromatin from cells during the early stages of meiosis and sporulation. They had molecular weights of approx. 51,000, $49,000,48,000$ (and 46,000) and were absent or highly reduced in glucose grown exponential cells and in stationary phase cells in glucose presporulation medium (Figure 3). The 51,000 molecular weight band was also found in chromatin from cells growing exponentially in a medium with potassium acetate as the carbon source (Figure 4). It thus appears that the presence of this band is induced by potassium acetate in the medium rather than being directly associated with sporulation. The 49,000 and 48,000 molecular weight bands seem to increase in concentration between 0 and 6 to 9 hours after stationary, sporulation competent cells were transferred to sporulation medium (Figure 6). During this period the majority of cells undergo meiotic DNA replication and enter meiotic prophase (12), suggesting a role of these polypeptides in meiotic interphase and prophase. Since the bands were also found in chromatin from non-sporulating diploids at 7.5 hours in sporulation medium (Figure 7), they are either not specific for meiosis or they are synthesized in preparation to meiosis, but not utilized in the non-sporulating strain. As to the nature of the 49,000 and 48,000 polypeptides, solubility properties indicate that they are closely related. The staining intensities indicate that they are major polypeptides in the yeast chromatin during sporulation conditions. It should be mentioned that actin isolated from a Dictyostelium species (kindly provided by C. MACLEOD,
University of California, San Diego) was found to have electrophoretic mobilities in SDS gels identical to the 49,000 band.

In a study of in vivo labelling of proteins associated with the folded chromosomes of yeast a few polypeptide band were found in the meiotic replicating form of the folded chromosome of yeast, which were not seen in the other isolated genome forms (13). Since the meiotic replicating form is not formed in non-sporulating diploids (15), they appear to be meiosis specific. Polypeptides which might correspond to these have not been identifiable in the chromatin patterns of the present study, presumably because they are minor constituents in chromatin preparations and therefore not easily demonstrated by staining.

\section{ACKNOWLEDGEMENTS}

The numerous discussions with M. C. KIELland-Brandt, T. Nilsson-Tillgren, S. HolmBERG and B. CHRISTENSEN and the critical reading of the manuscript by D. voN WeTtSTEIN are gratefully acknowledged. The isolations of labelled chromatin and folded genomes were performed during a stay in the laboratory of R. PIÑN to whom I am most grateful.

\section{REFERENCES}

1. Bhargava, M. M. \& H. O. Halvorson: Isolation of nuclei from yeast. J. Cell Biol. 49, 423-429 (1971)

2. Byers, B. \& L. Goetsch: Electron microscopic observations on the meiotic karyotype of diploid and tetraploid Saccharomyces cerevisiae. Proc. Nat. Acad. Sci. USA 72, 5056-5060 (1975)

3. Croes, A. F.: Induction of meiosis in yeast. II. Metabolic factors leading to meiosis. Planta (Berl.) 76, 227-237 (1967)

4. Esposito, R. E. \& M. S. Esposito: Genetic recombination and commitment to meiosis in Saccharomyces. Proc. Nat. Acad. Sci. USA 71, 3172-3176 (1974)

5. Esposito, M. S., R. E. Esposito, M. Arnaud \& H. O. Halvorson: Acetate utilization and macromolecular synthesis during sporulation of yeast. J. Bact. 100, 180-186 (1969)

6. Hopper, A. K., P. T. Magee, S. K. Welch, M. Friedman \& B. D. Hall: Macromolecule synthesis and breakdown in relation to sporulation and meiosis in yeast. J. Bact. 119, 619-628 (1974) 
7. Kraig, E. \& J. E. Haber: Effect of environment and genotype on the synthesis of abundant proteins during sporulation of Saccharomyces cerevisiae. Spores, in press (1981)

8. Kraig, E. \& J. E. Haber: Messenger ribonucleic acid and protein metabolism during sporulation of Saccharomyces cerevisiae. J. Bact., in press (1981)

9. LaemmLI, U. K.: Cleavage of structural proteins during the assembly of the head of bacteriophage T4. Nature 227, 680-685 (1970)

10. Leighton, T., F. Leighton, B. Dill \& J. Stock: The similarities of ribosomal and basic chromosomal proteins from fungi. Biochem. Biophys. Acta 432, 381-394 (1976)

11. Petersen, J. G. L., M. C. Kielland-Brandt \& T. Nilsson-Tillgren: Protein patterns of yeast during sporulation. Carlsberg Res. Commun. 44, 149-162 (1979)

12. Petersen, J. G. L., L. W. Olson \& D. Zickler: Synchronous sporulation of Saccharomyces cerevisiae at high cell concentrations. Carlsberg Res. Commun. 43, 241-253 (1978)

13. Petersen, J. G. L. \& R. Piñon: In vivo labelling of proteins associated with folded chromosomes of yeast. Carlsberg Res. Commun. 44, 395-402 (1979)

14. Petersen, J. G. L. \& W. F. Sheridan: High mobility group proteins in yeast. Carlsberg Res. Commun. 43, 415-422 (1978)

15. Piñon, R.: Folded chromosomes in meiotic yeast cells: Analysis of early meiotic events. J. Mol. Biol. 129, 433-447 (1979)
16. Piñon, R., Y. Salts \& G. Simchen: Nuclear and mitochondrial DNA synthesis during yeast sporulation. Exptl. Cell Res. 83, 231-238 (1974)

17. Roth, R. \& H. O. Halvorson: Sporulation of yeast harvested during logaritmic growth. J. Bact. 98, 831-832 (1969)

18. Sajdel-SulkowsKa, E. M., M. M. Bhargava, M. V. Arnaud \& H. O. Halvorson: An improved method for the isolation of yeast nuclei active in RNA synthesis in vitro. Biochem. Biophys. Res. Commun. 56, 496-502 (1974)

19. Silva-Lopez, E., T. J. Zamb \& R. Roth: Role of premeiotic replication and gene conversion. Nature 253, 212-214 (1975)

20. SimChen, G., R. Piñon \& Y. SAlts: Sporulation in Saccharomyces cerevisiae: Premeiotic DNA synthesis, readiness and commitment. Exptl. Cell Res. 75, 207-218 (1972)

21. Thomas, J. O. \& R. D. Korngerg: An octamer of histones in chromatin and free in solution. Proc. Nat. Acad. Sci. USA 72, 2626-2630 (1975)

22. Trew, B. J., J. D. Friesen and P. B. Moens: Two-dimensional protein patterns during growth and sporulation in Saccharomyces cerevisiae. $\mathbf{J}$. Bact. 138, 60-69 (1979)

23. WARNER, J. R.: The assembly of ribosomes in yeast. J. Biol. Chem. 246, 447-454 (1971)

24. WRIGHT, J. F. \& I. W. Dawes: Sporulationspecific protein changes in yeast. FEBS Letters 104, 183-186 (1979)

25. ZickLer, D. \& L. W. Olson: The synaptonemal complex and the spindle plaque during meiosis in yeast. Chromosoma (Berl.) 50, 1-23 (1975) 